\title{
GENETIC STRUCTURE OF ISOLATED Vaccinium oxycoccus POPULATIONS IN LITHUANIA
}

\author{
Judita Žukauskienè*, Algimantas Paulauskas*, Laima Česonienė**, \\ and Remigijus Daubaras** \\ * Vytautas Magnus University, Vileikos 8, Kaunas, LT-44404, LITHUANIA; \\ e-mail: Judita.Zukauskiene@fc.vdu.It \\ ** Kaunas Botanical Garden, Vytautas Magnus University, Z. E. Žilibero 6, Kaunas, LT-3018, LITHUANIA; \\ e-mail: r.daubaras@bs.vdu.It
}

Communicated by Īzaks Rašals

\begin{abstract}
The genetic population structure of the wild Cranberry Vaccinium oxycoccus was studied using RAPDs (random amplified polymorphic DNA). During the last century, intensive peat bogs drainage, regulation of water levels, and intensive cranberry picking has caused a risk for survival of wild cranberry Vaccinium oxycoccus populations in Lithuania. Genetic variation among and within isolated V. oxycoccus populations was investigated with RAPD profiles. Fifty-six clones were sampled in four populations at the Čepkeliai, Žuvintas, Kamanos Reserves and Aukštaitijos National Park. RAPD analyses of nine primers showed 213 polymorphic loci in the samples. The polymorphism level in the Čepkeliai rezerve population was $56.34 \%$, in Žuvintas $49.77 \%$, in Kamanos 46.95\% and in Aukštatija 43.19\%. Polymorphism among populations was $100 \%$. For the total sample group, Shannon's Information Index was 0.2 and Nei's gene diversity 0.12 . The estimated total proportion of diversity among populations (GST) and gene flow (Nm) were 0.14 and 3.1, respectively. The UPGMA analyses have revealed that populations of $\mathrm{V}$. oxycoccus are clearly separated into four lineages and only one Čepkeliai lineage had a homogenous haplotype. Others Žuvintas, Kamanos and Aukštatijos lineages differed from each other. One clone sampled from Aukštatija National Park (a8) had a unique haplotype.
\end{abstract}

Key words: genetic diversity, RAPD, isolated populations, Vaccinium oxycoccus.

\section{INTRODUCTION}

Loss of natural habitat due to human activities is widely recognised as the most important factor causing species decline world-wide (Sih et al., 2000). During the last century intensive peat bogs drainage, regulation of water levels, intensive cranberry picking has caused survival risk for wild cranberry Vaccinium oxycoccus populations in Lithuania. The amount and partitioning of genetic variation among and within populations results from the dynamic processes of gene flow, selection, inbreeding, genetic drift, and mutation (Harlt and Clark, 1994). In isolated populations genetic drift may eventually reduce genetic variation (Lacy, 1987; Ellstrand and Elam 1993; Frankham, 1996), especially because effective population sizes are usually much smaller than the number of reproductive individuals in a population (Frankham, 1995). At the same time genetic variation represents the starting point for further evolution and is an important prerequisite for the prediction of evolutionary responses. This is of practical significance in light of human-caused habitat fragmentation, alteration, or destruction (Fisher et al., 2000). Genetic structure among and within populations also depends on the life history of a species. Out crossing species tend to have higher levels of variability within populations but smaller degrees of differentiation among populations than selfing species (Brown et al., 1990; Schoen and Brown, 1991).

By definition genetic drift is selectively neutral. Therefore, it is best measured using selectively neutral genetic markers such as RAPD (random amplified polymorphic DNA) (Williams et al., 1990). Once established, RAPD-PCR (polymerase chain reaction) has the advantage of being quick and easy, requiring little plant material, and having a high resolution (Steinger et al., 1996; Gugerli et al., 1999). The aim of our study was to evaluate the genetic variability of $V$. oxycoccos from the Čepkeliai, Žuvintas, Kamanos Reserves and Aukštaitija National Park by the RAPD method.

\section{MATERIALS AND METHODS}

The $V$. oxycoccus is a perennial trailing woody vine that is native to bogs and swamps. Cranberry blooms during June and July, bearing ranks of solitary flowers along short up- 
right shoots that grow above the mat of vines (Butkus et al., 1987).

Fifty-six clones with clearly differing morphological features (colour, size, shape of berry and productivity) (Daubaras and Česonienè, 2004) were collected from three populations in Lithuania bogs (Čepkeliai, Žuvintas/ Kamanos and Aukštatija) during 1995-1999. Populations were geographically isolated: Čepkeliai $\left(54^{\mathrm{O}} 23^{\prime}-54^{\mathrm{O}} 30^{\prime} \mathrm{N}\right.$, $\left.24^{\mathrm{O}} 25^{\prime}-24^{\mathrm{O}} 35^{\prime} \mathrm{E}\right)$, Žuvintas $\left(54^{\mathrm{O}} 23^{\prime}-54^{\mathrm{O}} 30^{\prime} \mathrm{N}, 23^{\mathrm{O}} 25^{\prime}-\right.$ $\left.23^{\circ} 40^{\prime} \mathrm{E}\right)$, Kamanos $\left(56^{\mathrm{O}} 15^{\prime}-56^{\mathrm{O}} 20^{\prime} \mathrm{N}, 21^{\mathrm{O}} 35^{\prime}-22^{\mathrm{O}} 45^{\prime} \mathrm{E}\right)$ and Aukštatija $\left(55^{\circ} 40^{\prime}-55^{\circ} 00^{\prime} \mathrm{N}, 25^{\circ} 80^{\prime}-26^{\circ} 25^{\prime}\right)$.

DNA extraction and RAPD analysis were conducted as previously described (Nei and Li, 1997). Nine (OPA-1, OPA-2, OPA-5, OPA-9, OPA-10, OPB-11, ROTH-6, ROTH-8, ROTH-10) (Table 1). $10 \mathrm{nt}$ long primers of random sequence (Fermentas, Lithuania; Roth, Germany) were used. DNA amplification was performed in a thermocycler (Mastercycler, Eppendorf, Germany) under the following conditions: initial denaturation for $4 \mathrm{~min}$ at $94^{\circ} \mathrm{C}, 44$ cycles of denaturation for $1 \mathrm{~min}$ at $94{ }^{\circ} \mathrm{C}$, primers annealing for 1 $\min$ at $35^{\circ} \mathrm{C}$, extension for $2 \mathrm{~min}$ at $72{ }^{\circ} \mathrm{C}$ followed by a final extension for $5 \mathrm{~min}$ at $72{ }^{\circ} \mathrm{C}$.

Relationships among $V$. oxycoccus individuals were evaluated using a dendrogram based on Nei and Li's genetic distances (Areškevičiūtè et al., 2006) using the UPGMA (unweighted pair group method) cluster analysis. Calculation of genetic distances and UPGMA cluster analyses were performed with the TREECON programme for Windows $\mathrm{V}$ 1.3b (Nei and Li, 1979). Calculation of the observed num-

Table 1

USED PRIMERS, THE NUMBER OF BANDS PER PRIMER, AND THE RANGE OF MOLECULAR WEIGHT IN BASE PAIRS (BP) AMPLIFIED BY PCR FOR INDIVIDUALS OF $V$. oxycoccos

\begin{tabular}{l|c|c|c}
\hline Primer & $\begin{array}{c}\text { Sequence } \\
(5 \text { ' to 3') }\end{array}$ & $\begin{array}{c}\text { Range of molecular } \\
\text { weight }(\mathrm{bp})\end{array}$ & $\begin{array}{c}\text { Number of } \\
\text { bands }\end{array}$ \\
\hline OPA-01 & CAGGCCCTT & $125-2200$ & 30 \\
OPA-04 & AATCGGGCT & $225-2250$ & 21 \\
OPA-05 & AGGGGTCTT & $90-2000$ & 28 \\
OPA-09 & GGGTAACGC & $280-2750$ & 25 \\
OPA-10 & GTGATCGCA & $80-2000$ & 27 \\
OPB-11 & GTAGACCCG & $290-1900$ & 15 \\
$180-6$ & GCACGCCGGA & $80-1235$ & 19 \\
$180-8$ & CGCCCTCAGC & $300-1750$ & 17 \\
$180-9$ & GCACGGTGGG & $110-2400$ & 31
\end{tabular}

ber of alleles, Nei's (Peer et al., 1994; Nei and Nalt, 1973) gene diversity $(\mathrm{H})$, Shannon's Information Index (I), total gene diversity $(\mathrm{Ht})$, gene diversity within populations $(\mathrm{Hs})$, gene diversity among populations $(\mathrm{Gst}=(\mathrm{Ht}-\mathrm{Hs}) / \mathrm{Ht})$, gene flow $(\mathrm{Nm}=0.5(1-\mathrm{Gst}) / \mathrm{Gst})$ and generation of a Nei's genetic distance based dendrogram were carried out with POPGENE V 1.31 software (Yeh and Yang, 1999).

\section{RESULTS}

In our study, RAPD markers proved to be a powerful method for the detection of spatial genetic variation. Based on the literature (Nei and Li, 1979) we chose nine OPA and ROTH primers. Using nine primers (Table 1) we obtained 213 fragments and could differentiate the $56 \mathrm{~V}$. oxycoccus individuals, reflecting a rich allelic diversity among the populations.

The size of the amplified fragments ranged from 80 to 2750 bp, all loci were polymorphic. The number of bands per primer ranged from 15 (RAPD OPB-11) to 31 (RAPD ROTH-180-09). The polymorphism level in the Čepkeliai reserve population was $56.34 \%$, in Žuvintas $49.77 \%$, in Kamanos $46.95 \%$ and in Aukštatija 43.19\%.

To estimate genetic variation between populations, the Shannon's Information Index (I), Nei's gene diversity $(\mathrm{H})$ and the observed number of alleles per locus $(\mathrm{Na})$, number and percentage of polymorphic loci were calculated (Table 2 ). For the total sample, Shannon's Information Index was 0.2 and Nei's gene diversity 0.12 . The observed number of alleles per locus ranged from 0.16 in the Čepkeliai population to 1.5 in Kamanos and Žuvintas and 1.4 in Aukštatija population. The estimated total proportion of diversity among populations $\left(\mathrm{G}_{\mathrm{ST}}\right)$ and gene flow $(\mathrm{Nm})$ were 0.14 and 3.1 , respectively.

Shannon's index estimates of intraspecific genetic diversity within $V$. oxycoccus were slightly higher. The Shannon information index has general applications in ecology and is relatively insensitive to skewing effects caused by the inability to detect heterozygous loci (Dawson et al., 1995).

To estimate the relationship between $V$. oxycoccus populations, Nei's genetic distance between pairs of populations was calculated. Cluster analysis (UPGMA) was used to generate a dendrogram based on Nei's genetic distances among populations. It is noteworthy that from the same locality al-

GENETIC DIVERSITY OF LITHUANIAN POPULATIONS OF V. oxycoccus

\begin{tabular}{|c|c|c|c|c|c|}
\hline Population & $\begin{array}{c}\text { Shanon's Information } \\
\text { Index (I) }\end{array}$ & Nei's gene diversity $(\mathrm{H})$ & $\begin{array}{c}\text { Observed mean number } \\
\text { of alleles }(\mathrm{Na})\end{array}$ & $\begin{array}{l}\text { The number of } \\
\text { polymorphic loci }\end{array}$ & $\begin{array}{c}\text { The percentage of } \\
\text { polymorphic loci } \%(\mathrm{P})\end{array}$ \\
\hline Čepkeliai & 0.2357 & 0.1486 & 0.1563 & 120 & 56.34 \\
\hline Žuvintas & 0.1538 & 0.0896 & 1.4977 & 106 & 49.77 \\
\hline Kamanos & 0.1231 & 0.0674 & 1.4695 & 100 & 46.95 \\
\hline Aukštatija & 0.1914 & 0.1216 & 1.4319 & 92 & 43.19 \\
\hline Total & 0.2181 & 0.1166 & 2.0000 & 213 & 100.00 \\
\hline
\end{tabular}




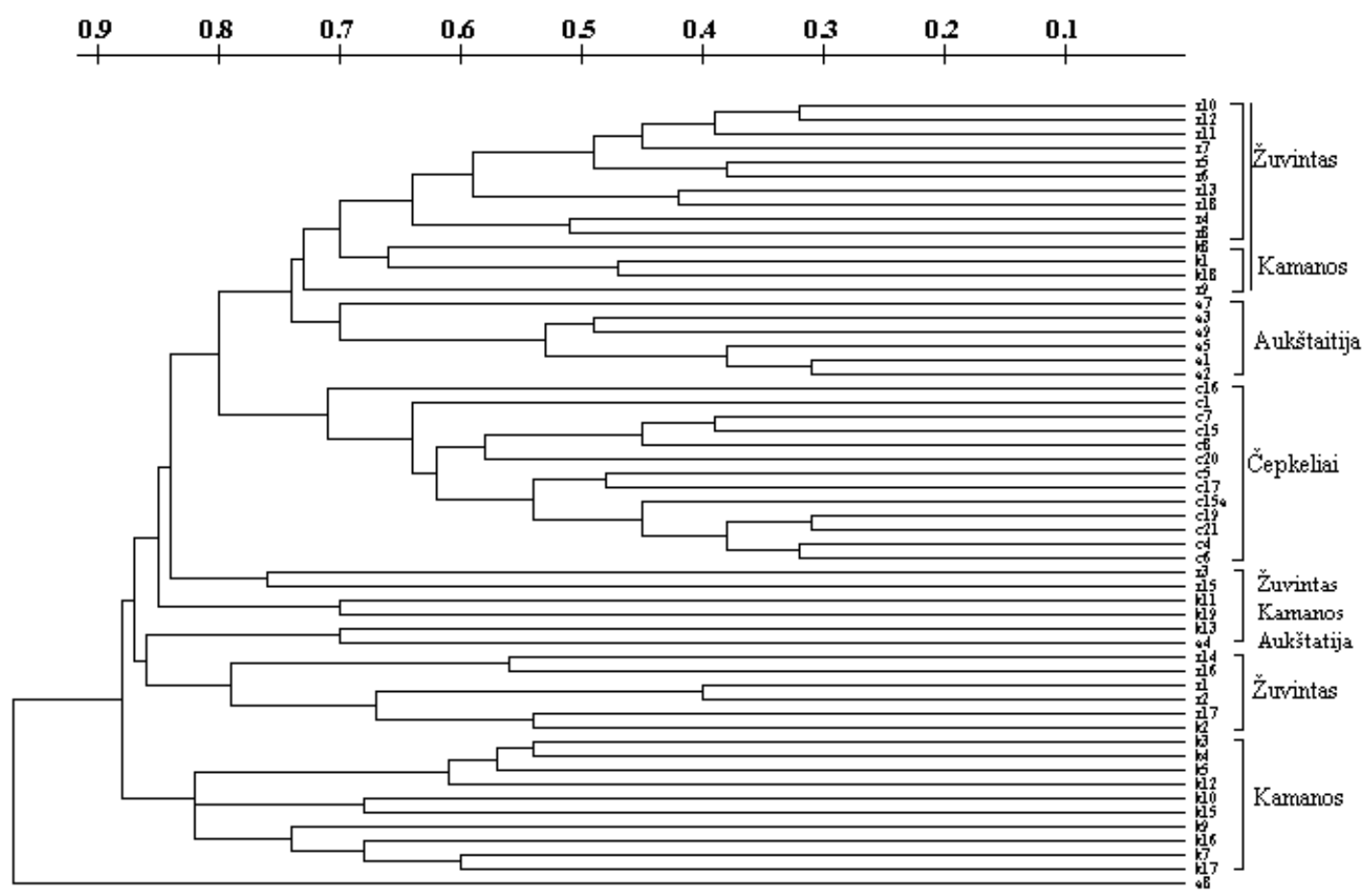

Fig. 1. UPGMA dendrogram based on Nei's genetic distances between individuals of $V$. oxycoccus from Lithuania.

cality always had the same haplotype while elsewhere in the distribution range clones differed (Fig. 1).

\section{DISCUSSION}

UPGMA analysis showed that populations of $V$. oxycoccus were clearly separated into four lineages and only one lineage (Čepkeliai) had a homogenous haplotype. The other lineages (Kamanos, Žuvintas and Aukštatija) differed from each other. One clone sampled from the Aukštatija National Park (a8) had a unique haplotype. The observed different and mixed lineages confirm the prediction that these two Lithuanian $V$. oxycoccus populations are ancestral to one population before glaciation and that the Čepkeliai population differed from them. One more factor that could have influenced the differences postglacial retreat in the populations of Čepkeliai, Žuvintas, Kamanos and Aukštatija (Webb and Bartelein, 1992) (Fig. 2). In the Lithuanian glaciation stage of pomeranija only asmall part of Lithuania was not covered by ice, which includes Čepkeliai Reserve. Thus, the Čepkeliai Bog represents the first bog uncovered by ice. In the next stage of ice retreat the Žuvintas Reserve Bog was uncovered (South Lithuanian ice retreat stage) later Aukštatija National Park (Midle Lithuania ice retreat stage) and followed by the Kamanos Reserve Bog (Fig. 2). According to Lithuania deglaciation periods, these four isolated populations genetically separated into different lineages (Fig. 1). The differences in the Čepkeliai population distinction could also be due to the river Nemunas. Many years ago this river was very wide restricting gene flow among populations.

The low genetic diversity within but high diversity among clonal plant populations is expected. On the other hand, in about $40 \%$ of clonal plant species reproduction by seeds is

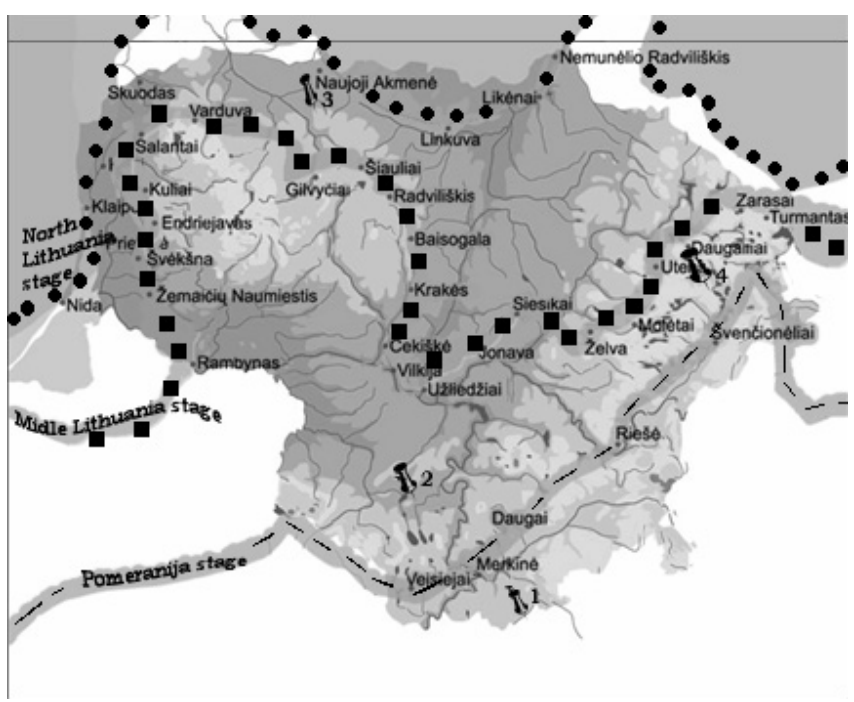

Fig. 2. Locations of sampling of isolated populations of $V$. oxycoccus from Lithuania (1 - Čepkleliai , 2 - Žuvintas, 3 - Kamanos rezerves, 4 Aukštatija national park). Different lines on Lituania map show different Lithuania glaciation stages. Line with dots - North Lithuania, line with square - middle Lithuania, line with dashes - Pomeranija glaciation stage.

observed (Kreher et al., 2000). Studies of genetic varaition in $V$. Statimeneteum, Viola riviniana and other clonal plant species reported high levels of genetc diversity within populations (Kreher et al., 2000).

Our study showed a comparatively high level of DNA polymorphism in $V$. oxycoccus. RAPD indicates that Lithuanian $V$. oxycoccus appears to maintain a very high level of the total genotypic variance among populations (100\%) comparing to American V. macrocarpon (61\%) (Stewart and Exocoffier, 1996). However, low total genotypic variance (41-57\%) was found within Lithuanian $V$. oxycoccus popu- 
lations (Table 2) comparing to American $V$. macrocarpon (more than 91\%). This could be due to postglacial retreat and isolation of populations (Webb and Bartelein, 1992). One more reason that could reduce genetic variability of $V$. oxycoccus is intensive cranberry picking in autumn. Reduction of seeds leads to one-way cranberries reproductionclonal reproduction and this can cause small genotypic variance within populations.

\section{ACKNOWLEDGMENTS}

This work was partially supported by the Lithuanian Ministry of Education and Science programme and by the Norwegian Centre for International Cooperation in Higher Education (grant CCP 03/02: ENLINO Master programme network).

\section{REFFERENCES}

Areškevičiūtè, J., Paulauskas, A., Česonienė, L., Daubaras, R. (2006). Genetic characterisation of wild cranberry (Vaccinium oxycoccos) from Čepkeliai reserve by the RAPD method. Biologija, No. 1, 5-7

Brown, A.H.D., Clegg M.T., Kahler A.L., Weir B.S. (eds.) (1990). Plant Population Genetics, Breeding, and Genetic Resources. Sunderland, Massachusetts: Sinauer, pp. 43-63.

Butkus, V., Jasionis, I., Urbonas, V., Červokas, V. (1987). Mažieji Miško turtai [Lesser Hoard of Forest]. Vilnius. Mokslas. 206 pp. (in Lithuanian).

Daubaras, R., Česonienè, L. (2004). Phenotypic properties of clones of wild cranberry (Oxycoccus palustris Pers.) and their stability. Baltic Forestry. 10(2), 87-90.

Dawson, I.K., Simsons, A.J., Waugh, R., Powell, W. (1995). Diversity andgenetic differentiation among subpopulations of Gliricidia sepium revealed by PCR-based assays. Diversity Heredity, 74, 10-18.

Ellstrand, N.C., Elam, D.R. (1993). Population genetic consequences of small population size: Implications for plant conservation. Annu. Rev. Ecol. Systemat., 24, 217-243

Fisher, M., Husi, R., Prati, D., Peintinger, M., Kleunen, M., Schmid, B. (2000). RAPD variation among and within small and large populations of the rare plant Ranunculus reptans (Ranunculaceae). Amer. J. Botan., 87(8), 1128-1137.

Frankham, R. (1996). Relationship of genetic variation to population size in wild life. Conserv. Biol., 66, 1500-1508.
Frankham, R. (1995). Effective population size/adult population size ratios in wildlife: A review. Gen. Res., 66, 95-107.

Gugerli, F., Eichenberger, K., Schneller, J.J. (1999). Promiscuity in populations of the cushion plant Saxifraga oppositifolia in the Swiss Alps as inferred from RAPDs. Molec. Ecol., 8, 453-461.

Harlt, D.L., Clark, A.G. (1997). Principles of Population Genetics. Sunderland, Massachusetts: Sinauer. 542 pp.

Kreher, S.A., Fore, S.A., Collons, B.S. (2000). Genetic variation within and among patches of the clonal species, Vaccinium stamineum L. Mol. Biol., 9, 1247-1252.

Lacy, R.C. (1987). Loss of genetic diversity from managed populations: Interacting effects of drift, mutation, immigration, selection and population subdivision. Conserv. Biol., 1, 143-158.

Nei, M., Li, W.-H. (1979). Mathematical model for studying genetic variation in terms of restriction endonucleases. Proc. Natl. Acad. Sci. USA, 76, 5269-5273.

Nei, M.P. (1973). Analysis of Gene Diversity in Subdivided Populations. Proc. Natl. Acad. Sci. USA, 70, 3321-3323

Schoen, D.J., Brown, A.H.D. (1991). Intraspecific variation in population gene diversity and effective population size correlates with the mating system in plants. Proc. Natl. Acad. Sci. USA, 88, 4494-4497.

Sih, A., Jonsson, B.G., Luikart, G. (2000). Habitat loss: Ecological, evolutionary and genetic consequences. Trends Ecol. Evol., 15, 132-134.

Steinger, T., Korner, C., Schmid, B. (1996). Long-term persistence in a changing climate: DNA analysis suggests very old ages of clones of alpine Carex curvula.Oecologia, 105, 94-99.

Stewart, C.N., Jr., Exocoffier, L. (1996). Assessing population structure and variability with RAPD data: Application to Vaccinium macrocarpon (American cranberry). Evol. Biol., 9, 153-171.

Yeh, F.C., Yang, R.C. (1999). POPGENE (Version 1.31): Population Genetic Analysis Software. Alberta, University of Albertaand Tim Boyle Center for International Forestry Research.

Van de Peer, Y., De Wachter, R. (1994). TREECON for Windows: A software package for the construction and drawing of evolutionary trees for the Microsoft Windows enwironment. Comput. Appl. Biosci., 10, 569-570.

Webb, T. III, Bartelein, P.J. (1992). Global changes during the last 3 million years: Climatic controls and biotic responses. Annu. Rev. Ecol. Syst., 23, $141-173$.

Williams, J.G.K., Kubelik, A.R., Livak, K.J., Rafalski, J.A., Tingey, S.V. (1990). DNA polimorphisms amplified by arbitrary primers are useful as genetic markers. Nucleic Acids Res., 18, 6531-6535.

Received 10 October 2007

\section{LIETUVAS Vaccinium oxycoccus IZOLĒTO POPULĀCIJU ĢENĒTISKĀ STRUKTŪRA}

Ar RAPD molekulāriem marḳieriem tika pētìts ǵenētiskais polimorfisms vairākās Lietuvas izolētās savvaḷas dzērveṇu populācijās. Atrastas lıti būtiskas ǵenētiskās atšķirīibas starp pētītām populācijām, tiek apspriests šo atšksirību cēlonis. 